\title{
THE RELIGIOUS LIFE HARMONY AND THE NATION'S INTEGRITY IN HISTORY VIEW
}

\author{
Neti Budiwati ${ }^{1}$
}

\begin{abstract}
In addition to a multi-ethnic and multi-cultural, Indonesian people's life is also multireligion/beliefs. This plural living conditions is prone to conflict. Most conflict happened is often ridden by religious issues and sentiments. Such circumstances should not be avoided to maintain the national integration. Plural life should be maintained in order to realize the the harmony of life in a multi-ethnic, multi-cultural, and multi-religious society.Therefore, the government issued UU Kerukunan Hidup Beragama (the Law on Religious Life Harmony) to achieve harmony in the society's life. In addition, one alternative to consider is to develop a civil society that is the embodiment of the nation as the realization of developing a nation that is advanced in every sector of development. The establishment of civil society must be understood as an aspiration to realize the democratic and infependent modern nation among the hustle and bustle of the differences. An ideal civilization will be able to build a nation with significant progress. The perspective of civil society in Indonesia is simple, to build a fair, open, and democratic society upon the foundation of the Almighty God. Therefore, to be developed in this kind of life is the constructive pluralism, which can be developed through multicultural education.
\end{abstract}

Key words: plural, harmony, civil, intimacy, multicultural

${ }^{1}$ Neti Budiwati lecturer of Indonesia University of Education (UPI). For academic interest, the author can be contacted at office address: Setibudhi street 229, Bandung, West Java. 


\section{Introduction}

Indonesia is a unitary state which is multiethnic, multi-cultural, multi-religious, and other diversity that is shown by the motto of "BhinekaTunggalIka (Unityin Diversity)". A slogan that has deep philosophical meaning, which become the adhesive of Indonesian society in a unity territory of Indonesia, one homeland, one nation and one language, which is born by the event of Sumpah Pemuda (the Oath of the youth).

One conflict-sensitive diversity is the diversity of religions and beliefs. The various religions and beliefs express the heterogeneity as well as the picture of the recognition of every citizen's right about the belief in god. According to the number of its adherents, of course there are the majority and the minority, therefore this religious rights of the majority and the minority should be maintained because both sides have rights. This is guaranteed by the constitution, so there is no principle of marginalization, particularly the alienation, to occur as opposed to the concept of human rights set out in the legislation. These conditions imply that the harmony in implementing the religion and belief in Indonesia, and perhaps in another multi religion country, is an important issue. It is government's duty to ensure the life comfort and safety of the religious believers.

The religious harmony is important because it is one of the factors that supporting the harmony of the nation. The basic concept of harmony does not lie in the religion, but the people of their respective religions. The religious harmony shows the relationship of all the people that is based on tolerance, mutual understanding, mutual respect, respect on equality and the practice of their religion in the social, state, and nation life. The understanding of religious harmony does not mean to mix some beliefs into one belief, but each belief do their own practice without harassing another belief, peacufully and friendly in diveristy. Given that the religious beliefs of one another is different, then the of inter-religious beliefs is not to be argued or synchronized. The appreciation and understanding for each other's faith is defined as tolerance, because tolerance should be built on the awareness and understanding of the needs and beliefs of others, not personal needs and beliefs.

However, the fact that we see in Indonesia today is conflict often happen which is caused by religious background, in addition to the decline of tolerance, mutual help, and solidarity in social life. The religious people of Indonesia must live side by side in order to create harmonious society arrangements for a harmonious life to and interact toward a common goal, the spiritually and physically wealthy society. Therefore, the importance of religion as the guide to improve the attitude of mutual respect requires its followers to carry the consistent responsibilities and mandate to create harmony between in a society with various religions.

The issue of the fading religious tolerance is reported by the Center of Strategic and International Studies / CSIS (2012). CSIS's study result in February 2012 in 23 provinces, involving 2,213 respondents, showed that the Indonesian religious tolerance is low. This is because even though the public is willing to accept the fact that they live in diversity, but most of them are actually hesitant to tolerate the diversity. Besides, other indication is that during the UN Human Rights Council 
evaluating the progress of the Human Rights implementation in Indonesia and 13 other countries in the world in the 13th session on 21st May to 4th June 2012, it indicate that religious tolerance in Indonesia is decreasing. This condition is unfortunate, the friendly Indonesia is now just a story. (Harian Pikiran Rakyat, 11 Juni 2012).

Given the pretty high number of cases/ events which generally occured in urban areas, as shown in Table 1 , it is a concern that should be immediately handle to minimal. A survey conducted by CSIS explained this condition is apparently at odds with the people who claim to be democratic. They claim to be democratic, but can not embody the values of democracy and respect for diversity. This is a stumbling block for Indonesia, who are maintaining its diversity.

The handling if this problem requires the participation of all segments of society, especially the government. On April 3, 2012 the House of Representatives has approved a draft bill of Social Conflict Management Act to be a law, and the current government has also filed a bill the Religious Life Harmony. The question is, is the social and religious conflicts could be resolved by the law of Conflict Handling and the Law of Religious Life Harmony, while the presence of the Act and the bill still contains problems and polemics?

It is interesting to study, and this paper will try to analyzetheproblem by focusing on the issue of religious harmony in Indonesia related to the integration of the nation, by bringing up issues that are formulated as follows: 1) How is the picture of the religious harmony in Indonesia society?; 2 ) How is the picture of problems/conflicts between religions and beliefs that occur in Indonesia?; 3) what factors are driving and inhibiting the nation's integration?, and 4) what is the proper solution to maintain the nation's integration realted to the religious harmony?

\section{Religion and Beliefs in Indonesia}

The independence day of Indonesian was declared on August 17, 1945, but the process to get to the independence day is long. Indonesian nationalism could be tracked through process of national organizations establsihment of Budi Utomo, on May 20, 1908, followed by the Youth Pledge of 1928. The process was crucial towards achieving the independence of Indonesia. From this national history events, could be understood that Indonesia was not born or appear out of nowhere, but through a process of dealing with the various differences if ethnicity, race, religion, and inter-group conflict.

Pluralism that gave rise to the differences is a special color for the lives of Indonesian people, and should be an assets that could develop Indonesia into a great country. One of the differences is the religious life and beliefs in Indonesia. Regarding the religion, Nasution in Syihab (2010: 54) make a list of some religion definitions:

1. Recognition of the human relationship with the supernatural forces that must be met.

2. Recognition of the existence of supernatural forces that dominate human.

3. Committed itself to a form of life, which contains a confession to a source that is outside human self and the influence of human actions. 
4. The belief of a supernatural power resulted in a certain way of life.

5. A code of conduct that originated from a supernatural power.

6. Recognition of the obligations which are believed to stem from a supernatural force.

7. Worship of supernatural forces that arise from feelings of weakness and fear of the mysterious power exist in human's surrounding.

8. The teachings of God revealed to man through the Apostle

Meanwhile Darraz (Shihab, 2010: 5556), also mentions the religious definition of some western scholars, which include:

1. Immanuel Kant (1724-184), religion is a sentiment feelings towards our duty, as it is the God's commandments.

2. Herbert Spencer 911820-1903), religion is the belief in a power which place or time is not possibly imagined.

3. E.B. Taylor (1832-1917), religion is the belief in the spiritual embodiment.

4. Max Muller (1823-1900), religion is an attempt to imagine something that is impossible to imagine, say something that is not possible to say, it is an attempt to look at the infinite, and it is the love of God.

5. Emile Durkheim (1858-1917), religion is a system collection of beliefs and deeds relating to something sacred, taboo, the beliefs and deeds that unite its followers in a single moral entity called religion. “

Religion and beliefs have different meanings but sometimes equated. The fact is a religion is always based on the belief of the religion's teachings. Darraz (Shihab, 2010: 57) suggests five essential elements that distinguish religion/belief and the behavior to be considered a religion or not:

1. The purification in religion is purification on a Dhat that have special properties, such as; unseen, and can not be felt by the senses.

2. The supernatural dhat in religion, is not part of this universe, but it has a positive power, influence, and powerful according to the will and iradah.

3. Such force, although not part of this nature, it has a meaningful relationship with nature and man. It hears all prayers and human complaints, it noticed the human grief and hope, and in accordance to it will, it can provide and answer the prayer and hope of human .

4. The power believed in religion is the highest and holiest power, all-powerful and are not controlled, given the submission and not subject to any and everyone.

5. The submission in religion is the submission based on the willingness and awareness; prostrate and worshiped what one beliefs on one's own will without forced.

Religion demands obedience/ submission of their followers, and of course every religion teaches good for its followers. This means that even there is religious diversity in this country it does not necessarily make any follower of a religion to be arrogant/cocky and selfish with no respect for other religions, because no religion teaches such thing. Some of the factors that led to the unity of Indonesia is a manifestation of heterogeneity, of the economic, cultural, or religious. "Nowadays the people of Indonesia have had a certain 
level of unity in religiously. Islam, the official religion of the majority Indonesian, has also contributed to the formation of the unity in the domain of culture. But we cannot ignore the fact of the basic patterns of the Indonesian ancestor's belief and its mistical in ancient times, which gives the same background for religious experience, including the areas that have the influence of Christianity and Islam. Furthermore, the influence of Hinduism and Buddhism is not only in Bali. In Java, the influence can still be clearly traced in the cultural and religious life. Islamic belief, as is believed in the kingdoms of Central Java coast, contains many elements that are absorbed from Hinduism and animism. Syncretic religion is sometimes even referred specifically as: Religion of Java. "(Wertheim, 1999: 7)

\section{Religion and The Nation}

Geographically, historically and ethnic, the social and national life in Indonesia is in diversity. Geographically, Indonesia diversity is indicated by many large and small islands scattered resulting in cultural isolation. Historically, travel/life processes resulted in civilization. And in terms of ethnicity, the diveristy is not in the racial sense, although some other racial elements (such as religion/belief and language) are seen in some Indonesia's ethnics.

Wikipedia reveals Islam first arrived in Indonesia in the 7th century through Arab traders. Islam spread to the west coast of Sumatra and then developed to the east of the island of Java. In this period there are several Islamic kingdoms, the kingdom of Demak, Pajang, Mataram and Banten. At the end of the 15th century AD, 20 Islamic empire was established, reflecting the dominance of Islam in Indonesia. Catholicism was brought to Indonesia by the Portuguese, especially on the island of Flores and Timor. Protestant Christianity was first introduced by the Dutch in the 16th century AD by the influence of Calvinist and Lutheran teachings. Animist region in eastern Indonesia, and other parts, are the main objectives of the Dutch people, including Maluku, Nusa Tenggara, Papua and Kalimantan. Later, Christianity spread through the coastal ports of Borneo, the misionaries arrive in Toraja, Sulawesi. Sumatra also became the target of the missionaries at the time, especially the Batak people, where many of them become Protestants.

Religion and society are like fish and water, two things that can not be separated. Both were born and grown almost together. Religion is basically building values based or rooted on the supernatural belief, the source of a society, because the norms of the provisions of what is forbidden and what is allowed is the code of conduct of a person or the society. Therefore, people need the norms to develop and grow. In contrast, the norms were born to manage the relationship between human beings, human beings and other creatures or the nuniverse, the human environment (Rahardjo, 2010: 78). With religion life is beautiful and fun, with religion life is in order so that the government have a lighter load. This is the ideal religion when it is understood and practiced in accordance with the teachings and the whole purpose of religion by its adherents.

According to Bennabi (Shihab, 2010) religion is a "catalyst" that always present behind the birth of a civilization in history. It "was a real natural phenomenon that 
controls thought and civilization, as magnets attract objects and dominate the development of object". A phenomenon that seems to have been contained (form) in a real natural law, a particular law of the mind that is spinning in an axis, in different circles, ranging from Islam to the worship of statues and the most primitive beliefs, which lights attratct our interes and forever misterious." Further Bennabi said, that "when it recognizes the expression of different religions, the goal is to build a religious phenomenon that is perennial as the characteristics of human, human beings are therefore described as homo riligious (the religious beings). Therefore religion is not only a spiritual and mental activity of the human, but as a fundamental human tendencies and the cosmic fact that rooted in the nature structure. "

What is revealed by Bennabiaboveleads us to realize that life can not be separated from the religious life. Throughout his life, man can not be separated from religious life because of the religion. Bronislow Malinowsky (1984-1942), Max Weber (1864-1920) and Sigmund Freud (18561939) agreed on a very basic point, that "religion is a phenomena that characterize all human societies; past, present and future". Meanwhile Carl Gustave Jung (1875-1961) argued that "religion is one of the earliest and the most universal human mind activities ". (Shihab, 2010)

The case in our country has raised a question, why religious conflicts ofte happen? In this multicultural life, the life of modern society will find the majority and minority groups demanding recognition of their identities, and their acceptance of cultural differences (including differences and religious beliefs). This is a challenge of multuculturalism. It means that the intra-religious conflicts is due to the demands of their existence, and it demands to understand the precise meaning of multiculturalism. Related to this issue, Kymlicka (2002: 13) elaborates: "generalizations about the purpose or the consequences of multiculturalism can be very misleading. Indeed, much of the public debates on multiculturalism suffer because of its misguided. For example, those who oppose multiculturalism often say that it makes the minority fragmented like in the geto and disrupt their integration in the majority society; multiculturalism supporters respond that the concern of integration refelects the cultural imperialism. Both of these charges are excessive generalization, ignoring the differences that exist between groups of minority and misinterpret their truly motives." In this case, it is make sense for all components of the nation understand that all the difference is the capital in building better lives for the sake of national integration in order to remain solid in the inevitable globalization.

\section{Religious Life Harmony and The Nation's Integration}

In Earlier, have been presented the results of a survey that conducted by CSIS suggested that the tolerance of religious life in Indonesia is low. In addition, the results of the evaluation conducted by the UN Human Rights Council said that the matter of religious tolerance in Indonesia is increasingly degenerate. The UN evaluation is based on a series of violent events against religions and beliefs in Indonesia during 2011-2012, as shown in the table below: 
Table 8.1

Violent Events Regarding Religions and Beliefs In Indonesia During 2011 -2012

\begin{tabular}{|l|l|l|}
\hline No & Time & Incident \\
\hline 1 & 20 May & $\begin{array}{l}\text { HKBP Filadelfia } \\
\text { church in Bekasi, } \\
\text { West Java was } \\
\text { obstructed and } \\
\text { throwned with plastic } \\
\text { glasses and rotten } \\
\text { eggs by a number of } \\
\text { people. The incident } \\
\text { was done by a group } \\
\text { of people who do not } \\
\text { agree with HKBP } \\
\text { Filadelfia activities } \\
\text { conducted in their } \\
\text { neighborhood. }\end{array}$ \\
\hline 2 & 9 May 2012 & $\begin{array}{l}\text { The discussion even } \\
\text { of Irshad Manji, } \\
\text { author 'Allah, Cinta } \\
\text { dan Kebebasan', } \\
\text { was dismissed by } \\
\text { hundreds of people. } \\
\text { The mass brought } \\
\text { flyers of Majelis } \\
\text { Mujahidin Indonesia } \\
\text { and smashed and } \\
\text { ransacked the } \\
\text { discussion venus } \\
\text { at lembaga kajian } \\
\text { Islam dan Sosial, } \\
\text { jl. Sorowajan Baru, } \\
\text { Bantul Yogyakarta. } \\
\text { They accused taht } \\
\text { Irshad Manji bring } \\
\text { atheism in disguise. }\end{array}$ \\
\hline
\end{tabular}

\begin{tabular}{|l|l|l|}
\hline 3 & 6 May 2012 & $\begin{array}{l}\text { Tantowai Anwari, an } \\
\text { activist and journalist } \\
\text { from the Serikat } \\
\text { Jurnalis untuk } \\
\text { Keberagaman (Sejuk) } \\
\text { was tortured while in } \\
\text { the HKBP Filadelfia } \\
\text { by a group of people } \\
\text { who do not agree } \\
\text { with the worship } \\
\text { activities of HKBP } \\
\text { Filadelfia. }\end{array}$ \\
\hline 4 & $\begin{array}{l}\text { The Ahmadiyah } \\
\text { mosque in the village } \\
\text { of Babakan Sindang, } \\
\text { Cipakat, the district } \\
\text { of Singaparna } \\
\text { Tasikmalaya was } \\
\text { destroyed by a } \\
\text { mass. Destruction } \\
\text { is allegedly caused } \\
\text { by the reopening of } \\
\text { Ahmadiyah mosque } \\
\text { which was sealed } \\
\text { by the society some } \\
\text { time before the } \\
\text { incident. There were } \\
\text { no casualties in the } \\
\text { incident. }\end{array}$ \\
\hline 5 & $\begin{array}{l}\text { About 20o people } \\
\text { pelted the roof of the } \\
\text { building and knock } \\
\text { down the back wall } \\
\text { of the Nurhidayah } \\
\text { mosque belonging } \\
\text { to Ahmadiyah on } \\
\text { Ciranjang main road } \\
\text { at Cisaat Village, } \\
\text { Cianjur Regency } \\
\text { West Java. }\end{array}$ \\
\hline
\end{tabular}




\begin{tabular}{|l|l|l|}
\hline 5 & $\begin{array}{l}17 \text { February } \\
2012\end{array}$ & $\begin{array}{l}\text { About 20o people } \\
\text { pelted the roof of the } \\
\text { building and knock } \\
\text { down the back wall } \\
\text { of the Nurhidayah } \\
\text { mosque belonging } \\
\text { to Ahmadiyah on } \\
\text { Ciranjang main road } \\
\text { at Cisaat Village, } \\
\text { Cianjur Regency } \\
\text { West Java. }\end{array}$ \\
\hline 5 & $\begin{array}{l}17 \text { February } \\
2012\end{array}$ & $\begin{array}{l}\text { About 20o people } \\
\text { pelted the roof of the } \\
\text { building and knock } \\
\text { down the back wall } \\
\text { of the Nurhidayah } \\
\text { mosque belonging } \\
\text { to Ahmadiyah on } \\
\text { Ciranjang main road } \\
\text { at Cisaat Village, } \\
\text { Cianjur Regency } \\
\text { West Java. }\end{array}$ \\
\hline 6 & $\begin{array}{l}\text { Allegedly because } \\
\text { of disagreement, a } \\
\text { number of people } \\
\text { who claim as the } \\
\text { Sunni poeple } \\
\text { attacked mosques } \\
\text { and school belong } \\
\text { to the Syiah people } \\
\text { in the village of } \\
\text { Karang Gayatri, Kab. } \\
\text { Sampang, East Java. } \\
\text { As the result of the } \\
\text { incident four houses, } \\
\text { a shop, the school } \\
\text { building, and musala } \\
\text { are heavily damaged. }\end{array}$ \\
$\begin{array}{l}\text { The house owned by } \\
\text { Moh Siri (56), the } \\
\text { folloewr of Syiah in } \\
\text { Sampang, East Java } \\
\text { was burnt. }\end{array}$ \\
\hline 7
\end{tabular}

\begin{tabular}{|c|c|c|}
\hline 8 & $\begin{array}{l}\text { 1-2 August } \\
2011\end{array}$ & $\begin{array}{l}\text { The worship place } \\
\text { allegedly unlicensed } \\
\text { which belong to the } \\
\text { christians in the } \\
\text { district of Kuansing } \\
\text { Riau was burned by } \\
\text { number of people. } \\
\text { The place was } \\
\text { actually a house, } \\
\text { but was used as a } \\
\text { place of worship. } \\
\text { The location of the } \\
\text { first burn in Dusun } \\
\text { Sungai Langsat, } \\
\text { Desa Pasarbaru, } \\
\text { Kecamatan Pangean } \\
\text { dan yang kedua } \\
\text { di Desa Logas, } \\
\text { Kecamatan Logas }\end{array}$ \\
\hline 9 & $\begin{array}{l}16 \text { May } \\
2011\end{array}$ & $\begin{array}{l}\text { Easter celebration } \\
\text { and the graduation } \\
\text { celebration in } \\
\text { Gedung Gratia } \\
\text { Cirebon which } \\
\text { was attended by } \\
\text { about 6,ooo people } \\
\text { was dismissed by } \\
\text { approximately } 20 \\
\text { people who claimed } \\
\text { to be from the Ormas } \\
\text { Gapas. They yelled } \\
\text { at the organizers } \\
\text { and claimed that } \\
\text { the service in the } \\
\text { building are not } \\
\text { authorized and } \\
\text { should be disbanded. } \\
\text { The police then came } \\
\text { to intervene and } \\
\text { asked to dismiss the } \\
\text { event for security } \\
\text { reasons. }\end{array}$ \\
\hline
\end{tabular}




\begin{tabular}{|l|l|l|}
\hline 10 & $\begin{array}{l}8 \text { February } \\
2011\end{array}$ & $\begin{array}{l}\text { Some people was } \\
\text { in tantrum in } \\
\text { Temanggung District } \\
\text { Court because } \\
\text { they did not accept } \\
\text { the verdict for a } \\
\text { defendant charged } \\
\text { with blasphemy, } \\
\text { Antonius Bawengan } \\
\text { Richmind. As the } \\
\text { result, court window } \\
\text { was broken, a car } \\
\text { was on fire and } \\
\text { three churches was } \\
\text { damaged. }\end{array}$ \\
\hline 11 & $\begin{array}{l}\text { 6 February } \\
\text { 2011 }\end{array}$ & $\begin{array}{l}\text { A mass attacked } \\
\text { Ahmadiyah followers } \\
\text { in Cikeusik, } \\
\text { Tangerang regency, } \\
\text { Banten. It is reported } \\
\text { that three people } \\
\text { killed in the incident. }\end{array}$ \\
\hline 12 & $\begin{array}{l}\text { Dozens of Front } \\
\text { Pembela Islam (FPI) } \\
\text { people was rallied } \\
\text { 2011 Januar knowing that } \\
\text { there are activities } \\
\text { on Ahmadiyah } \\
\text { mosque in Makassar. } \\
\text { Consequently, the } \\
\text { Ahmadiyah people } \\
\text { was evacuated to } \\
\text { An Nushrat mosque } \\
\text { at Jl Anuang 112, } \\
\text { Makassar. }\end{array}$ \\
\hline
\end{tabular}

Source: Harian Pikiran Rakyat, 11 June 2012
If we observed, the intolerance problem was highlighted by the UN is apparently merely based on the reports of two cases, which are the case of Ahmadiyah and HKBP Bekasi. Besides, the problem of intolerance is not only happening in Muslim-majority of Indonesia. The same problem also occurs in India, for example, the majority of Hindus are also often "disrupt" the mosque. In Italy they ban veiled women. These cases actually shows that intolerance is not only the problem of the Muslims (as is widely alleged in Indonesia), elsewhere muslims are the victims. It is associated with the diversity/multicultural issues related to the minority groups as a counter to the majority group, as described in the previously..

When compared with the United States and other western countries or other countries which Islam is the minority, religious tolerance in Indonesia is very beautiful and high. It can be seen from mosques and churches building that stand side by side. The most obvious example, in the city of Jakarta, where Masjid Istiqlal which the pride of Muslims is just across the street from a Catholic church. In Bali, we can find mosques, churches and temples are standing side by side. The miniature of religious harmony in Indonesia can also be found in Taman Mini Indonesia Indah (TMII) featuring the building of worship houses of the recognized religions in Indonesia which are standing side by side.

The following table shows the violence and abuse of religion in some countries. 
Table 8.2

Religion Violence and Abuse in Various Developed Countries

\begin{tabular}{|l|l|l|}
\hline No & Time & Incident \\
\hline 1 & 4 June 2012 & $\begin{array}{l}\text { A group of young } \\
\text { men armed with } \\
\text { hammers and } \\
\text { iron attack three } \\
\text { Jewish students } \\
\text { in Lyon, France. } \\
\text { These three Jewish } \\
\text { students, who are } \\
\text { all wearing typical } \\
\text { hat of Jewish, } \\
\text { were attacked after } \\
\text { leaving the Jewish } \\
\text { school. Two of the } \\
\text { victims should be } \\
\text { treated for injuries } \\
\text { suffered in the } \\
\text { head and neck. }\end{array}$ \\
\hline 2 & $\begin{array}{l}\text { Someone unknown } \\
\text { threw Molotov } \\
\text { cocktails at a } \\
\text { mosque run } \\
\text { Imam al-Khoel } \\
\text { foundation in New } \\
\text { York City, USA. In } \\
\text { addition, a home } \\
\text { that is being held } \\
\text { Hindu service and } \\
\text { a grocery store did } \\
\text { not escape from } \\
\text { the attack. There } \\
\text { were no casualties } \\
\text { in the incident. }\end{array}$ \\
\hline
\end{tabular}

\begin{tabular}{|l|l|l|}
\hline 3 & 11 April 2011 & $\begin{array}{l}\text { Senior members } \\
\text { of the British } \\
\text { National Party } \\
\text { (BNP), Sion Owens } \\
\text { (40), were arrested } \\
\text { and detained by } \\
\text { South Wales Police } \\
\text { to have proven to } \\
\text { burn a Quran at } \\
\text { his home garden. }\end{array}$ \\
\hline 4 & 23 September & $\begin{array}{l}\text { Six Britons } \\
\text { detained after } \\
\text { a video clips } \\
\text { showing scenes of } \\
\text { burning the Quran } \\
\text { is circulating in the } \\
\text { internet. However, } \\
\text { the accused is } \\
\text { released on bail } \\
\text { pending further } \\
\text { investigation. }\end{array}$ \\
\hline 5 & 15 September \\
2010 & $\begin{array}{l}\text { An ice cream } \\
\text { company that had } \\
\text { been banned for } \\
\text { its add featuring } \\
\text { a pregnant nun } \\
\text { Catholic trying to } \\
\text { post the similar } \\
\text { posters in London } \\
\text { during the Pope } \\
\text { visit. British } \\
\text { Advertising } \\
\text { Standard } \\
\text { Authority (ASA) } \\
\text { had commanded } \\
\text { that advertising } \\
\text { does not proceed } \\
\text { by reason of } \\
\text { conviction } \\
\text { insulting Catholics. }\end{array}$ \\
\hline
\end{tabular}




\begin{tabular}{|c|c|c|}
\hline 6 & $\begin{array}{l}\text { Early } \\
\text { September } \\
2010\end{array}$ & $\begin{array}{l}\text { The Dove World } \\
\text { Outreach Center } \\
\text { (DWOC) in } \\
\text { Florida, United } \\
\text { States, led Pastor } \\
\text { Dr. Terry and } \\
\text { Sylvia Jones } \\
\text { campaigned for } \\
\text { burning the Quran } \\
\text { on the anniversary } \\
\text { of the World } \\
\text { Trade Center } \\
\text { (WTC) tragedy. } \\
\text { The campaign } \\
\text { was posted on } \\
\text { a web page and } \\
\text { social network. } \\
\text { They claim to } \\
\text { be on behalf of } \\
\text { the Christian } \\
\text { community. } \\
\text { However, the } \\
\text { campaign received } \\
\text { harsh criticism } \\
\text { from the Christian } \\
\text { communities both } \\
\text { from and outside } \\
\text { the United States. }\end{array}$ \\
\hline 7 & $\begin{array}{l}27 \text { March } \\
2007\end{array}$ & $\begin{array}{l}\text { An anti-Islam } \\
\text { movie called } \\
\text { 'Fitna The Movie' } \\
\text { was released by a } \\
\text { Dutch citizen Geert } \\
\text { Wilders who is } \\
\text { also a politician. } \\
\text { The movie was } \\
\text { criticizing Islam, } \\
\text { and could give } \\
\text { rise to the fear of } \\
\text { Islam. }\end{array}$ \\
\hline
\end{tabular}

\begin{tabular}{|l|l|l|}
\hline 8 & $\begin{array}{l}\text { 4-6 August } \\
2008\end{array}$ & $\begin{array}{l}\text { Anti-immigrant } \\
\text { Danish People's } \\
\text { Party (DFU) } \\
\text { organized } \\
\text { a drawing } \\
\text { competition } \\
\text { of Prophet } \\
\text { Muhammad } \\
\text { cartoons in } \\
\text { Denmark. This } \\
\text { is the second } \\
\text { case of insult } \\
\text { to the Prophet } \\
\text { Mohammed in } \\
\text { Denmark after } \\
\text { the case of Jyland } \\
\text { Posten. }\end{array}$ \\
\hline 9 & $\begin{array}{l}\text { October 2008 } \\
\text { Denmark's TV2 } \\
\text { channel broadcast } \\
\text { video footage made } \\
\text { by members of } \\
\text { far-right Danish } \\
\text { People's depicting } \\
\text { the Prophet } \\
\text { Muhammad as } \\
\text { a terrorist camel } \\
\text { beer drinkers } \\
\text { who attacked } \\
\text { Copenhagen. }\end{array}$ \\
\hline 2005 September & $\begin{array}{l}\text { Twelve caricatures } \\
\text { of the Prophet } \\
\text { Muhammad } \\
\text { published in } \\
\text { Jyland Posten } \\
\text { newspaper. } \\
\text { Jyland Posten is } \\
\text { Denmark's largest } \\
\text { newspaper. }\end{array}$ \\
\hline
\end{tabular}

Source: Harian Pikiran Rakyat, 11 June 2012 
Although the Indonesian government recognizes a number of different religions, the inter-religious conflict is sometimes inevitable. During the New Order era, Soeharto issued legislation which perceived as anti-Chinese by some community. President Suharto tried to restrict anything related to Chinese culture, including the name and religion. As a result, Buddhism and Confucianism have been exiled. (Wikipedia). Furthermore Wikipedia outlines as follows:

Between 1966 and 1998, Suharto sought to de-Islamization of government, by providing a greater proportion of the Christians in the cabinet. But in the early 1990s, the issue of Islamization that appears, and military split into two groups, nationalist and Islamic. Islamic groups, led by General Prabowo, pro-Islamization, while General Wiranto from nationalist groups, adhering to the secular state.

During the Soeharto era, Indonesia's transmigration program continued, once activated by the Dutch government in the early 19th century. Purpose of this program is to move people from crowded areas like the island of Java, Bali and Madura to less populated areas, such as Ambon, the Sunda Islands and Papua. This policy got a lot of criticism, regarded as colonization by the Javanese and Madurese, who brought Islam to non-Muslim areas. Residents in western Indonesia are mostly Muslims and Christians are a small minority, while the eastern region, the Christian population is equal to or even greater than the population of Muslims. It became the main driver of conflict between religion and race in eastern Indonesia, such as the case of Poso in 2005.

The government had intended to lessen conflict or tension with the nomination of interfaith cooperation. Ministry of Foreign Affairs, together with Indonesia's largest Islamic organization, Nahdlatul Ulama, which is held by the International Islamic scholar, introduce moderate Islam, which is believed to reduce the tension. On December 6, 2004, there was interreligion conference on the theme "Dialog Kooperasi Antar Agama: Masyarakat Yang Membangun dan Keselarasan" (Inter-religion Cooperation Dialogue: the Building Community and Harmony). Countries present at the conference is the ASEAN member countries, Australia, East Timor, New Zealand and Papua New Guinea, which is intended to discuss the possibility of cooperation among different religious groups in minimizing conflicts between religions in Indonesia. Australian Government, represented by its foreign minister, Alexander Downer, strongly support the conference. It can be concluded that the conflict in Indonesia has a long history. As a multicultural country, every regime in this country has the same task of creating harmony result in frequent conflict with different backgrounds.

We still remember, for example, how the carelessness of the New Order era in managing issues of ethnicity that must be paid by the outbreak of inter-ethnic conflict in the late 1990 s and early 2000 . Ethnic conflict in Ambon, Sampit, Sambas, and tragedy in 1998 which took a lot of casualties among the Chinese ethnic are a real example of how ethnic diversity in Indonesia has not been able to be a blessing in social (thesocial capital), but it becomes a source of political unrest and the latent turn makes the country worse. These conflicts are often linked to religious issues. Conflict in Ambon, for example, the 1999 conflict was obvious actually not 
a problem of conflict between religions (Islam and Christianity), as well as with the events of 2011.

\section{Maintaining the Nation's Integrity}

The word integrity is closely related to the formation of a nation, as a nation composed of various elements such as ethnic, race, tradition, belief and so diverse. For the integration of a nation is due to the combination of different elements, so as to create territorial integrity, political unity, economic, social and culture that shape the nation's identity. National integration does not just happen, but require a long course of time the process has to start a life together. Thus national integration can mean the union of different parts of a whole society into a more complete, or integrate the many small communities that a lot number to a nation.

A problem of national integration in Indonesia is complex and multidimensional. To realized it justice and policies implemented by the government are needed, with no distinction of race, ethnicity, religion, language, gender, and so on. In addition, efforts to build justice unity of the nation are part of the effort to build and maintain political stability and the role played by the government and society collectively.

Therefore, the effort of national integration with solid strategy needs to be done constantly in order to realize the desire integration of the Indonesia. The effort of developing and maintaining the national integration is necessary, because essentially the national integration showed the strong levels of unity and national unity desired. In the end this national unity may ensure the realization of a prosperous, safe and secure country. If we look at the conflict in Aceh, Ambon, West Kalimantan, and Papua, these conflict are the reflection of the undeveloped of the expected national integration.

To get variety of complications and concerns about national integration conflicts, the other side of the conflict should be examined. According to Dahrendorf, conflict may also be seen as a natural mechanism in the context of social reconstruction to find a new balance in the society. Therefore, according to this, analysis of violent conflict happened nowadays may be directed to identify the elements of disintegration, and then eliminate these elements in order to achieve a new balance. The most prominent disintegrative elements as explained above are extremities, social trust deficit and the collapse of human values. (Qhoha, 2011).

In order to maintain the nation's integration, the factors supporting and inhibiting integration of the nation should be known. The factors driving national integration including:

1. Historical factors that give rise to a sense of kinship and arms.

2. The desire to unite among the people of Indonesia as stated in the Sumpah Pemuda (the Youth Pledge )of October 28, 1928.

3. A sense of patriotism among the people of Indonesia, as proved by the struggle to achieve, enforces, and fulfills the independence of Indonesia.

4. The sense to sacrifice for the sake of the nation and the state, as evidenced by the many national heroes who died on the battle field.

5. National consensus in the realization of the Declaration of Independence, 
Pancasila and the 1945 Constitution, the flag, the national anthem of Indonesia Raya, the national language of Bahasa Indonesian.

6. The existence of state symbols in the form of Garuda Pancasila, with the motto of Bhineka Tunggal Ika (Unity in Diversity).

7. Cultural development of mutual assistance that are the characteristic of Indonesian national identity for generations.

While the factors that inhibiting to the national integration include:

1. The heterogeneous (diverse) Indonesia society in the factors of ethnicity with each of its local culture, language, region, religion, race and so on.

2. Vast areas of the country, consists of thousands of islands surrounded by vast oceans.

3. The amount of possible threats, challenges, obstacles and distractions that undermine the integrity, unity and national unity, both from within and outside the country.

4. Thebiggap of inequality of development and development results rise to a sense of dissatisfaction and despair in SARA (Ethnic, Religion, Race, and Group) issues, and regional separatist movements, demonstrations and protests.

5. The existence of "ethnocentrism" concept among some ethnic groups that highlight the advantages of their culture and despise other ethnic cultures.

6. The weak of national cultural values due to the strong influence of foreign culture that does not comply with national identity, either through the direct contact or indirect contact.

7. The direct contact such as through the elements of tourism, while the indirect contact such as through print of media (magazines, tabloid), or electronic media (television, radio, movies, the Internet, cell phones or facilities which feature complete)

\section{The religious Tolerance as the Gate of the National Integration: Developing a Civil Society}

The inter-religious conflict (intolerance) may threat the national integration, therefore it is necessary to find a solution. It must be admitted that with many religions and cults that exist in Indonesia, inter-religious conflict is inevitable. To handle the necessary participation of all parties, both public and government officials, because of the convenience of living should be guaranteed by the state and this will happen when one of them achieved religious harmony. The next will be the capital for the creation of harmonious life of the nation as a whole (macro). It should be remembered that religious harmony is not uniting religion, but coexist with mutual respect and appreciate the teachings of their respective religions and this requires its adherents to tolerate each other.

Related to the above issue, Sadjijono (2009) says: "freedom of religion is the Basic Human Rights. This basic right is the Human Right. The Religious rights of every citizen of Indonesia is stated as part of human rights as set out in the Article 4 and Article 22 paragraph (1) and paragraph (2) of Law no. 39 Year 1999 on Human Rights, as the right that can not be reduced under any circumstances and by anyone. Therefore the state gives 
citizens freedom to have religion, but cannot determine which religion for who. The Implementation of "freedom" in state law can not be implemented as free as you like, but it is based on the applicable law, including the freedom to have religion and worship according to his religion. Thus having religion and doing its worship is based on what stipulated on the law"

Therefore, one of the concrete solutions is the need for inter-religion "dialogue", as called upon by the the Chairman of Nahdlatul Ulama (NU), Indonesia, Said Aqil: "Let's have dialogue to resolve this issue. An open dialogue with each other. Dialogue between the religion figures, inter-elite, so that this problem can be solved in a good manner". One activity that has been taken is the Pekan Kerukunan Antar-Umat Beragama (World Interfaith Harmony Week) 2012 on February 2012.

How about the government plan to form the Religious Harmony Act? Although the bill is currently in the Parliament, there are still pros and cons. The cons assumed that the life of religion is a fundamental right of every person that does not need to be regulated directly by the state, while the pros say, by having the law it could at least minimize the inter-religion conflict. The harmonious relations between religious communities are one element of the realization of peace and public order. In general, realization of a safe, orderly, and peaceful society is the responsibility of the state. This is the reason why the Government wishes to pass the Bill for Religious Harmony (RUU KUB/ Kerukunan Umat Beragama) into the law of KUB. The decision is postpones because therea are still alot pf pros and cons.

Moreover, on April 3, 2012, the House legalized a bill on Social Conflict
Management (RUU Penanganan Konflik Sosial) into law, but this law is still an issue and criticized. This kind of condition makes the religion problem harmony is doubtfully will be handled properly. The term to live harmoniously for the sake of national integrity is up to the personal commitment of each citizen. Could it be a way out to be taken is to create a civil society (masyatakat Madani), which actually had been also aspired by the government? Speaking of masyarakat madani, it is certainly related to the issue of nationalism. "As a reform movement, nationalism will achieve a very fundamental ideals, which is the formation of civil society (masyarakat madani). The idea of masyarakat madani is intensively analyzed by many thinkers and national figures; given that idea is a manifestation of building a truly advanced nation in every sector of development. The establishment of masyarakat madani must be understood as an aspiration to realize the modern nation state that is democratic, free, inclusive and cosmopolitan. The Sumpah Pemuda have shown that the crystallization of the modern concept of nationalism is the liberating character “. (Illahi, 2012; 31).

An ideal civilization would be able to build a nation in which significant progress. Sufyanto (2001: 120) considers that "the perspective of civil society in Indonesia is simple, to build a fair, open, and democratic society on the foundation of God. With noble values, such as tolerance and pluralism as well as the continuation of keabadan values." Meanwhile, Illahi (2012) asserts that the "the national integrity and security is more important than the sectoral arrogance that spur the ethnic and regional conflict .... . Do not ever let this country torn to pieces just because of the prominence of sectoral, regional 
and the group interests. In this case we are developing the constructive pluralism, not implementing the minority by force or minoroty by will.

\section{The important of Multicultural Education: Alternative Solution}

The ethnic diversity that we have is our strength and wealth as long as we remain grounded in the realization of Wawasan Nusantara as a whole insight of the social and cultural. Various styles and cultural diversity is an invaluable asset not good for the development of our personality as well as our nation's attractive character in international arena. We should maintain the style and cultural diversity that we have in order to build a harmonious life. Conflict, however small will hurt us. This fact demonstrates the need for that ethnic diversity to be actually realized as the national assets.

Lubis (2005) says that "the wrong understanding of the relationship between ethnic identity, cultural expression, and resources control, particularly in the context of heterogeneoussocialenvironmentispotentially become the source of ethnic tensions." Conflict prevention efforts is needed, such as through multicultural education.

Komara in the Harian Pikiran Rakyat, March 8, 2012, is interesting, which raised the issueof "Promoting Multicultural Education". The idea can be seen as novelty, but it is not necessarly new, because it actually has grown since after the World War II as the resistance againts racism. As said by Minderovic (2004) in Maliki (2010: 251): "Multicultural education can be used as a resistance to the idea of Nazi racism by pointing to an appreciation of cultural pluralism, tolerance, freedom, equality and humanism or humanity." In the Indonesian, on the formal educational application contexts it may be considered as new, but for non-formal education it is not a new thing, because there are already examples such as the "Desantara Foundation" in Depok West Java as multikulutural school.

Desantara Foundation, often conducts training in various area of Indonesia on various issues and subject of studies; criticism of religious discourse, multicultural women, and cultural studies. The issues brought to the training is labeled as "Multicultural Education". As the name implies, it always focused on the issue of multiculturalism as a reflection of the diversity that has long been inscribed in the cultural experience of Wawasan Nusantara. "Diversity is a fact that can not be denied. Nonetheless, the fact that our live have a number of differences, should not hide the right to life and security of manifestation of human values individuals and groups in society.

Multiculturalismisa concept, a paradigm, as well as experience on how diversity is interpreted. Although there are variety of opinions on the meaning of multiculturalism, the normative understanding of how we see the difference, to manage for survival together is the crucial issues discussed, and spread through various level of society of Indonesia. We all have to live and experience the meaning of diversity in society. Unfortunately the positive meaning of life in diversity is less sowing as the collective normative knowledge." (Desantara, 2009).

Komara (2012) in his article stated that "Multicultural Education is a response 
to the development of the diversity of the school population, as demands equal rights for every group. Multicultural education begins with the development of ideas and awareness of multiculturalism. This is related to the political and social developments. Multiculturalism is a concept that can meet the challenges of changing era on the grounds that glorifies multiculturalism is an ideology or a belief that differences and promote cultural pluralism as a form of social life, which is aiming to realize the anti-racist education ... “

Theexplanation aboveis astrong reason for developing multicultural education in the education system in Indonesia. In addition, in line with paragraph 1 of article 21 of the 1945 Constitution "that every citizen have the right to receive education ". As well as the United Nations (UN) agencies through the UNESCO (United Nations Educational, Scientific and Cultural Organization) which launched the four pillars of education for today present and the future: (1) learning to Know, (2) learning to do (3) learning to be, and (4) learning to live together.

The four pillars are described as follows, With learning to know UNESCO is stressing that children should acquire the correct knowledge as much as possible. Learning to do is defined as the direction of the second pillar on the ability to act and work. Extensive knowledge should be applied to be used as an action and good works. Learning to be is the attitude of tolerance or feel "being" towards others. Learning to live together is people should learn to live with other people or socialize in the community. Understanding of the role of self and others in the study group is a provision in socializing in the community (learning to live together).

These four pillars when applied correctly, it has been in line with what is done at the time of independence, the unification of the people of Indonesia through the process of National and Character Building with the motto of Bhineka Tunggal Ika (Unity in Diversity.) Living together habit, mutual respect, open, giving and receiving should be developed in schools. These conditions allow the growth of mutual understanding among racial, ethnic, and religious. Education in schools should also stimulate the soft skills of students so that someday they can live together with others, able to work together with others. In fact they are trained to be sensitive to other people's joys and sorrows. How is the form of education to achieve this?

Komara article and Sekolah Multikultural Desantara has answered few questions of multicultural education in our country. Within the meaning of nonformal education, Desantara school is one of real attempts to answer the question of how to maintain harmony in the midst of multicultural "jungle" of life. Within the meaning of formal education at all levels of schooling, it still need more study, like in America that change their curriculum, or another solution forms. Related to this, Maliki (2010: 266) says that "in fact the national education curriculum has incorporated the multicultural education as a subject of study in sociology for high school, but the problem may be the subject of multicultural education has not been fully realized by the actors of education. If yet been realized, perhaps it has not 
been effectively implemented." Therefore, according to Maliki (2010), cited what was raised by Quezda and Romo (2004) which says that the for an effective transformation of multicultural education there are 4 dimensions that should be concern:

1. Curriculum renewal, which also transformed the knowledge from the historicalresearch.Thelearningmaterials that support awareness of the importance of multicultural openness to face reality, can be obtain by detecting bias of various writings, media educational materials. In addition to the renewal of curriculum theory itself.

2. When students learn about justice and inclusive communities, students are directed to the challenges of building a fair society.

3. When students have the opportunity improve the sensitivity and multicultural competence, the student's multicultural competencies should include understanding the culture of ethnic groups, efforts to reduce prejudice and ethnic identity development.

4. The increase of multicultural competence is also related to the pedagogy of justice, school and classroom climate, student performance, the culture patterns while teaching and learning.

\section{Conclusion}

From the explanation in the previous section, the conclusion is as follows:

1. That the religious harmony in Indonesia today is allegedly intolerant, although when viewed physically very tolerant and harmonious, as seen from the adjoining house of worships. However, the majority-minority theory explains that interreligious conflicts can occur because minorities always want to show their identity.

2. The inter-religious conflict in the last one and a half years (2011 - June 2012) makes every citizen of Indonesia very concern, there are 12 cases that are quite prominent, and this is an issue raised for the UN Human Rights Council to show the presence of religious intolerance in Indonesia.

3. The integration of one nation can be formed and maintained through the life of inter-religion harmony, and also by other factors, such as economic aspects and citizens responsibilities/commitments.

4. In order for the country's integration in the context of religious tolerance can be maintained, then the solution offered is to establish Masyarakat Madani. Although not easy, but it is a goal to be realized.

5. In addition to establishing Masyarakat Madani, to instill awareness of living in a multicultural society from an early age is also important.It could done by multicultural education as one of the alternative solutions that should be try.

Therefore, this paper recommends that the plural life, as said by Furnivall, should be to laid out in order to maintain the harmony in multi-ethnic society. Conflicts and attacks to the worship places only resulted in the material and spiritual losses, if this happens repeatedly it will be a great loss because economically it will suck the capital or the "social". It will finally demand us to not deny the multi-ethnic life or this diversity, there are dynamics that 
give lessons of life in diversity. "Pluralism often attract attention because of problems associated with inter-group conflict and socialdisintegration.Actually, thepluralism has a boarder dynamics and diversity of the social dimensions sociologically rather than simply the presence or absence of conflict. We need to explore and understand the dynamics of social interactions and the social patterns that includes the realtion of rights and obligations and the realtion of power among the actors that are deep, complex and invisible (hidden).

\section{REFERENCES}

Abdullah, H. M. A. (2003). Agama dan Pluralitas Budaya Lokal. Surakarta: Mahammadyah University Press.

Abdullah, T. (1984). "Kesadaran Sejarah Masa Kini: Perdebatan Tentang Hari Sumpah Pemuda" in William H. Frederick dan Soeri Soeroto. Pemahaman Sejarah Indonesia. Jakarta: LP3ES.

Akhyar, Y. L. (2006). Deskontruksi Epistemologi Modern.Jakarta: Pustaka Indonesia Satu.

Bachtiar, W.H. (2001) "Integrasi Nasional Indonesia" dalam Indra J. Piliang, Edy Prasetyono, Hadi Soesastro, Merumuskan Kembali Kebangsaan Indonesia. Jaka rta: Centre for Strategic and International Studies.

Banks, J. A. (1977).Multiethnic Education; Practices and Promises. Bloominton, Indiana: The Phi delta Kappa Educational Foundation.

Banks,J.A.(1993)“MulticulturalEducation for Young Children: Racial and Ethnic
Attitudes and Their Modification”. In

B. Spodek (ed). Handbook of Research on the Education of Young Children,. New York: Macmillan.

Burnett, G. (1994). Varieties of Multicultural Education: An

Introduction. Eric Clearinghouse on Urban Education: New York. N.Y

Berry, J.W, Ed. (1999). Psikologi Lintas Budaya Riset dan Aplikasi. Alih Bahasa: Edi Suhardono, Jakarta: PT Gramedia.

Cabral, A. (1979). Unity and Struggle: Speeches and Writing. terjemahan bahasa Inggeris oleh Miichael Wolters, New York : Monththly Review Press. Eliade, M. (2002). Sakral dan Profan. Penterjemah Nuwanto, Yogyakarta: Fajar Pustaka Baru.

Gollnic, D.M., \& Chinn, P.C. (1990) Multicultural education in pluralistic society (3rd ed). Columbus, O.H: Merrill.

Ilahi, M.T. (2012). Nasionalisme Dalam Bingkai Pluralitas Bangsa, Paradigma Pembangunan \& Kemandirin Bangsa. Jogjakarta: Ar-Ruzz Media.

Jandt, F. E. (1998). Intercultural Communication An Introduction. Thousand Oaks: Sage Publication.

Kymlicka, W. (2002) Kewargaan Multikultural. Terjemahan Edlina Hafmini Eddin, Jakarta: LP3ES.

Kahin, G.McT. (1995). Nasionalisme dan Revolusi di Indonesia. Jakarta: Sinar Harapan.

McLemore, S. D. (1980). Racial and Ethnic Relations in America. Boston: Allyn and Bacon, Inc.

Piotr, A. (2010). Sosiologi Perubahan Sosial. Jakarta: Prenada Media Group. 
Rahardjo, D. (2001), Merayakan Kemajemukan Kebebasan dan Kebangsaan. Jakarta: Kencana Pranata media Group

Sufyanto. (2001). Masyarakat Madani: Kritik Hermeneutika Masyarakat MadaniNurcholisMadjid.Yogayakarta: Pustaka Pelajar.

Usman, S. (2010). Membangun Peradaban dengan Agama. Jakarta: Dian Rakyat.

Sadjijono dalam http://gagasanhukum. wordpress.com/2009/)

Sleeter, C.E. (1992). Keepers of the American dream: A study of staff development and multicultural education. London: The Falmer Press.

Sleeter, C.E., \& Grant, C.A. (1993). Making Choices for Multicultural Education: Five Approaches to Race, Class and Gender (2nd ed.). New york: Merrill.

Supardan, D. (2002). Keberhasilan Kebijakan Multikulturalisme Kanada dan Tantangannya: Studi Hak Azasi Manusia dalam Perspektif Global. Jurnal Pendidikan Ilmu Sosial (JPIS), Bandung: FPIPS UPI

Wesley, E.B., dan Wronski. (1958). Teaching Social Studies in High School. Boston: D.C. Health).

W.F. Wertheim. (1999). Masyarakat IndonesiadalamTransisi.Yogayakarta: Tria Wacana
Weiner,M.(1996). "Kebijakan Preferensial” dalam Roy C. Macridis dan Benard E. Brown. Perbandingan Politik. Alih Bahasa A.R. Henry Sitanggang. Jakarta: Erlangga.

Wiriaatmadja, R. (1993). Peranan Pengajaran Sejarah Nasional Indonesia dalam Identitas Nasional (Upaya Peraihan Nilai-nilai Integralistik dalam Proses Sosialisasi dan Enkulturasi Berbangsa di Kalangan Siswa SMAK I BPK Penabur Bandung). Sejarah 3, Jakarta: MSI dengan PT Gramedia Pustaka Utama.

Wiriaatmadja, R. (2002). Pendidikan Sejarah di Indonesia: Perspektif Lokal, Nasional, dan Global. Bandung: Historia Utama Press.

Zainuddin, M. (2010). Sosiologi Pendidikan. Yogyakarta: Gadjah Mada University Press.

Zulkifli B. L. (2005). Kanalisasi Ketegangan Etnik dan Kompetisi Budaya Dalam Sektor Publik, dalam ETNOVISI, Jurnal Antropologi Sosial Budaya, Vol. 01 No. 2 Oktober 2005 , ISBN: 0216-843x

Harian Pikiran Rakyat, 8 Maret 2012 Harian Pikiran Rakyat, 11 Juni 2012 Harian Kompas, 17 April 2012 